\title{
DIRECT CURRENT AND PULSED DIRECT CURRENT PLASMA NITRIDING OF FERROUS MATERIALS A CRITICAL REVIEW
}

\author{
Magdalena ŁĘPICKA ${ }^{*}$, Małgorzata GRĄDZKA-DAHLKE \\ *Faculty of Mechanical Engineering, Department of Materials and Biomedical Engineering, Bialystok University of Technology, \\ ul. Wiejska 45 C, 15-351 Bialystok, Poland \\ m.lepicka@pb.edu.pl, m.dahlke@pb.edu.pl
}

received 14 July 2015, revised 20 May 2016, accepted 25 May 2016

\begin{abstract}
Nowadays, the improvement of ferrous materials performance is a problem of high interest. One of well-known wear- and corrosion properties improving technique is plasma nitriding, in which elemental nitrogen is introduced to the surface of a metal part for subsequent diffusion into the material. As a result, a compound, "white" layer and a diffusion zone are formed at the detail's surface. Most of the authors positively describe the effects of surface ion nitiding. On the other hand, there are also reports on adverse effects of direct current and pulsed direct current plasma nitriding on ferrous materials performance. Therefore, an attempt to provide comprehensive summary on direct current and pulsed direct current ion nitriding and its influence on ferrous materials' mechanical and corrosion properties has been made. According to the results, some of the technique drawbacks are hard to avoid in mass production.
\end{abstract}

Key words: Plasma Nitriding, lon Nitriding, Direct Current Plasma Nitriding, Pulsed Direct Current Plasma Nitriding, Edge Effect

\section{INTRODUCTION}

Used in industry for more than 30 years (Soltani Asadi and Mahboubi, 2012), plasma nitriding (PN), called also ion nitriding or plasma ion nitriding (Szilágyiné Biró, 2013), has become an acceptable alternative to conventional gas nitriding because it is a non-pollutant, energy-saving and easy time- and temperature control process (Olzon-Dionysio et al., 2010; Brühl et al. 2010; Szilágyiné Biró, 2013). Currently it is used in a great number of industry branches, e.g. in automotive in engine components (Sirin and Kaluc, 2012), in order to maximize performance and service life of various ferrous materials, e.g. ferritic and austenitic steels, bearing steels, martensitic steels, as well as non-ferrous metals, such as titanium (Musil et al., 2000).

Nowadays, the plasma nitriding process is carried out by variety of methods. The most popular one is the DC (direct current) plasma nitriding, referred also to cathodic nitriding or conventional plasma nitriding (Musil et al., 2010; Li et al., 2014), which is extensively used in commercial ion nitriding reactors (Baldwin et al., 1998).

\section{GENERAL INFORMATION}

According to Li et al. (2010), in the DC nitriding process the components to be treated act as a cathode, whereas the grounded walls of the furnace form the anode. The treated material is directly involved in the discharge process. Typically, the applied voltage between the anode and the cathode is from 400 to $700 \mathrm{~V}$. The positive ions produced by glow discharge are accelerated near the cathode surface and bombard the surface of the treated specimen. Due to ion bombardment the active nitrogen is sputtered, the workpiece is heated and its surface is cleaned (Brühl et al., 2010; Sirin and Kaluc, 2012). As a result, the "white" layer and the diffusion layer with altered mechanical properties are formed. The "white" layer term originates from the white color on the microscopy of the compound layer after Nital etch application.

In particular, low-temperature plasma nitriding $\left(<420^{\circ} \mathrm{C}\right)$ of austenitic stainless steels such as AISI 304 or $316 \mathrm{~L}$ results in formation of a metastable austenite phase supersaturated with nitrogen atoms (nitrogen concentration is 20-30 at\%) (Madjarov and Russeva, 2007; Li et al., 2008; Wang et al., 2009). This phase is usually called expanded austenite, S-phase or yN (Toshkov et al., 2007; Li et al., 2008; Wang et al., 2009) and exhibits significant improvement in substrate hardness while the wear resistance is enhanced by several orders of magnitude (Menthe et al., 2000). What is more, some authors attribute $\gamma_{\mathrm{N}}$ excellent anticorrosive properties (Fossati et al., 2006b). In temperatures exceeding $420^{\circ} \mathrm{C}$, due to sufficient diffusivity of chromium in the austenite the precipitation of $\mathrm{Cr}_{x} \mathrm{~N}$ starts (Tab. 1,2), resulting in depletion of $\mathrm{Cr}$ from austenitic matrix and, usually, decrease in corrosion resistance (Wang et al., 2009). Unfortunately, the rate of plasma nitriding processes and nitrogen diffusion in temperatures below $450^{\circ} \mathrm{C}$ is low and leads to a very long duration of the nitriding process for getting appropriate layer thickness (Wang et al., 2013). As a result, the process becomes ineffective and too expensive to apply in mass production. According to the literature (Tab. 1), in order to obtain a $5 \mu \mathrm{m}$ nitride layer at least a $2 \mathrm{~h}$ lasting process must be applied (Li et al., 2008).

In martensitic stainless steels, the usually ca. $25 \mu \mathrm{m}$ thick (Podgornik et al., 1998) outer, compound layer consists mainly of $\gamma^{\prime}-\mathrm{Fe}_{4} \mathrm{~N}$ or $\varepsilon-\mathrm{Fe}_{2,3} \mathrm{~N}$ intermetallic phases - iron nitrides (Sirin and Kaluc, 2012; Mashreghi et al., 2013). Study by Weber et al. (Weber et al., 1995) revealed that the corrosion rate of iron in an acidic solution can be reduced by one order of magnitude when the $\varepsilon-\mathrm{Fe}_{2,6} \mathrm{~N}$ phases are formed, and reduced by three orders of magnitude by the formation of $y^{\prime}-\mathrm{Fe}_{4} \mathrm{~N}$. Composition and thickness of the "white" layer highly depends on the used in the nitriding process gas composition, treatment time and temperature 
(Tab. 1, 2), as well as the carbon content (Sirin and Kaluc, 2012). In general, the more homogenous and monolithic is the outer phase, the better. When nitriding martensitic steels, the homogenous monolayer can be obtained with elongation of treatment time (>15 h for AISI 4140) (Corengia et al., 2005). Nevertheless, temperature of $500^{\circ} \mathrm{C}$ must be applied. According to Corengia et al. (2004a), the single-phase $\mathrm{y}^{\prime}-\mathrm{Fe}_{4} \mathrm{~N}$ layers exhibit better tribological properties than two-phase compound layers. In supermartensitic stainless steels, beside the $\gamma^{\prime}-\mathrm{Fe}_{4} \mathrm{~N}$ and $\varepsilon-\mathrm{Fe}_{2,3} \mathrm{~N}$ intermetallic phases, $a_{N}$, the "nitrogen expanded martensite" phase is also distinguished (Kurelo et al., 2015).

Tab. 1. Data on the direct current (DCPN) plasma nitriding collected from the literature; $C D$ - case depth

\begin{tabular}{|c|c|c|c|c|c|c|}
\hline Material & Parameters & Temp. $\left({ }^{\circ} \mathrm{C}\right)$ & Time $(\mathrm{h})$ & Nitride layer characteristics & Hardness & Ref. \\
\hline AISI 1020 & $\begin{array}{l}350 \mathrm{~Pa} \\
\mathrm{~N}_{2}: \mathrm{H}_{2} 4: 1\end{array}$ & $400-480$ & 3 & $\begin{array}{l}\mathrm{Y}^{\prime}-\mathrm{Fe}_{4} \mathrm{~N}+\varepsilon-\mathrm{Fe}_{2,3} \mathrm{~N} \\
2.5-5 \mu \mathrm{m} \\
\mathrm{CD}: 30.3-58.5 \mu \mathrm{m}\end{array}$ & $350-500 \mathrm{HV}_{0.05}$ & (de Sousa et al., 2014) \\
\hline AISI 304 & $\begin{array}{l}2.67 \mathrm{~Pa} \\
\mathrm{~N}_{2}: \mathrm{H}_{2} 1: 4\end{array}$ & 500 & 8 & $\begin{array}{l}\gamma_{N} \\
4 \mu \mathrm{m}\end{array}$ & $600 \mathrm{VHN}_{25 g f}$ & (Balusamy et al., 2013) \\
\hline AISI 304 & $\begin{array}{l}100 \mathrm{~Pa} \\
\mathrm{~N}_{2}: \mathrm{H}_{2} 1: 3\end{array}$ & 400 & 8 & $\begin{array}{l}\gamma_{\mathrm{N}} \\
\mathrm{CD}: 51.7 \mu \mathrm{m}\end{array}$ & - & (Wang et al., 2013) \\
\hline AISI 304 & $\begin{array}{l}\text { 666-1332 Pa } \\
\mathrm{N}_{2}: \mathrm{H}_{2} 19: 1\end{array}$ & $450-570$ & 4 & $Y^{\prime}-\mathrm{Fe}_{4} \mathrm{~N}+\varepsilon-\mathrm{Fe}_{2,3} \mathrm{~N}+\mathrm{CrN}$ & - & (Borges et al., 2000) \\
\hline AISI 304 & $\begin{array}{l}100 \mathrm{~Pa} \\
\mathrm{NH}_{3}\end{array}$ & 420 & $2-44$ & $\begin{array}{l}\gamma_{N} \\
3-27 \mu \mathrm{m}\end{array}$ & $600-1200 \mathrm{HV}_{0.05}$ & (Wang et al., 2006) \\
\hline AISI 304 & $\mathrm{~N}_{2}$ & 420 & 6 & $\begin{array}{l}\mathrm{YN} \\
\mathrm{CD}: 12 \mu \mathrm{m}\end{array}$ & $15.4 \mathrm{GPa}$ & (Raman and Jayaprakash, 2007) \\
\hline AISI 304 & $\begin{array}{l}500 \mathrm{~Pa} \\
\mathrm{NH}_{3}\end{array}$ & $400-500$ & 2 & $\begin{array}{l}\gamma_{N} \\
2-13 \mu m\end{array}$ & $440-1300 \mathrm{HV}_{0.1}$ & (Liang et al., 2001) \\
\hline AISI 304L & $\begin{array}{l}200-600 \mathrm{~Pa} \\
\mathrm{~N}_{2}: \mathrm{H}_{2} 1: 4\end{array}$ & $350-480$ & $4-8$ & $\mathrm{~V}_{N}+\mathrm{CrN}+\mathrm{a}_{\mathrm{N}}$ & $630-1200 \mathrm{HV}_{0.1}$ & (Wang et al., 2009) \\
\hline AISI 316 & $\begin{array}{l}500 \mathrm{~Pa} \\
\mathrm{~N}_{2}: \mathrm{H}_{2} 1: 3\end{array}$ & $450-550$ & 5 & $\begin{array}{l}\mathrm{YN}+\mathrm{CrN} \\
15-60 \mu \mathrm{m}\end{array}$ & $1100-1500 \mathrm{HV}_{0.05}$ & (Sun and Bell, 1998) \\
\hline AISI 316 & $\begin{array}{l}667 \mathrm{~Pa} \\
\mathrm{~N}_{2}: \mathrm{H}_{2} 1: 3\end{array}$ & 450 & 5 & $\begin{array}{l}\mathrm{YN}_{\mathrm{N}}+\mathrm{y}^{\prime}-\mathrm{Fe}_{4} \mathrm{~N} \\
6 \mu \mathrm{m}\end{array}$ & - & (Karimzadeh et al., 2013) \\
\hline AISI 316L & $\begin{array}{l}500 \mathrm{~Pa} \\
\mathrm{NH}_{3}\end{array}$ & $520-560$ & $1 / 12-2$ & $\gamma_{N}+\mathrm{CrN}^{\prime} \gamma^{\prime}-\mathrm{Fe}_{4} \mathrm{~N} 1.5-12 \mu \mathrm{m}$ & $400-1200 \mathrm{HV}_{0.05}$ & (Li et al., 2014) \\
\hline AISI 316 & $\begin{array}{l}500 \mathrm{~Pa} \\
\mathrm{~N}_{2}: \mathrm{H}_{2} 1: 3\end{array}$ & $300-450$ & 20 & $\begin{array}{l}\text { YN } \\
2-20 \mu \mathrm{m}\end{array}$ & $1400-1600 \mathrm{HV}_{0.05}$ & (Bell, 2002) \\
\hline AISI 316L & $\begin{array}{l}530 \mathrm{~Pa} \\
\mathrm{~N}_{2}: \mathrm{H}_{2} 1: 4\end{array}$ & 400 & 4 & $\begin{array}{l}\gamma_{N}+\varepsilon-\mathrm{Fe}_{2+x} \mathrm{~N}+\gamma^{\prime}-\mathrm{Fe}_{4} \mathrm{~N} \\
1.5-2.3 \mu \mathrm{m}\end{array}$ & $183 \mathrm{HV}_{0.01}$ & (Olzon-Dionysio et al., 2010) \\
\hline AISI 316L & $\begin{array}{l}600 \mathrm{~Pa} \\
\mathrm{~N}_{2}: \mathrm{H}_{2} 1: 4\end{array}$ & $350-480$ & 2 & $\begin{array}{l}\gamma_{N}+\mathrm{CrN} \\
5 \mu \mathrm{m}\end{array}$ & $740-1100 \mathrm{HV}_{0.1}$ & (Li et al., 2008) \\
\hline AISI 316L & $\begin{array}{l}250 \mathrm{~Pa} \\
\mathrm{~N}_{2}: \mathrm{H}_{2} 1: 1\end{array}$ & 440 & 6 & $\begin{array}{l}\gamma_{N}+\mathrm{CrN} \\
3.5 \mu \mathrm{m}\end{array}$ & $1200 \mathrm{HV}_{0.05}$ & (Skolek-Stefaniszyn et al., 2010) \\
\hline AISI 316L & $\mathrm{N}_{2}: \mathrm{H}_{2} 1: 1$ & 440 & 6 & $\begin{array}{l}\mathrm{YN}_{\mathrm{N}} \\
20 \mu \mathrm{m}\end{array}$ & $1240 \mathrm{HV}_{0.05}$ & (Borowski et al., 2010) \\
\hline AISI 316L & $\begin{array}{l}1000 \mathrm{~Pa} \\
\mathrm{~N}_{2}: \mathrm{H}_{2} 4: 1\end{array}$ & 430 & $1-5$ & $\begin{array}{l}\mathrm{YN} \\
3-10 \mu \mathrm{m}\end{array}$ & $300-1400 \mathrm{HK}_{0.1}$ & (Fossati et al., 2006b) \\
\hline AISI 316L & $150-2000 \mathrm{~Pa}$ & 430 & 5 & $\begin{array}{l}\gamma_{N}+y^{\prime}-\mathrm{Fe}_{4} \mathrm{~N}+\mathrm{CrN} \\
9-15 \mu \mathrm{m}\end{array}$ & $1380-1430 H^{-0.01}$ & (Borgioli et al., 2006) \\
\hline AISI 316L & $\begin{array}{l}1000 \mathrm{~Pa} \\
\mathrm{~N}_{2}: \mathrm{H}_{2} 4: 1\end{array}$ & $400-500$ & 5 & $\begin{array}{l}\gamma_{N}+y^{\prime}-\mathrm{Fe}_{4} \mathrm{~N}+\mathrm{CrN} \\
4-47 \mu \mathrm{m}\end{array}$ & $373-1605 \mathrm{HK}_{0.1}$ & (Fossati et al., 2006a) \\
\hline AISI 316L & $\begin{array}{l}1000 \mathrm{~Pa} \\
\mathrm{~N}_{2}: \mathrm{H}_{2} 4: 1\end{array}$ & $400-500$ & 5 & $\begin{array}{l}\gamma_{N}+y^{\prime}-\mathrm{Fe}_{4} \mathrm{~N}+\mathrm{CrN} \\
4-47 \mu \mathrm{m}\end{array}$ & $800-1580 \mathrm{HK}_{0.01}$ & (Borgioli et al., 2005) \\
\hline AISI 316L & $\begin{array}{l}400 \mathrm{~Pa} \\
\mathrm{~N}_{2}: \mathrm{H}_{2} 1: 3\end{array}$ & 425 & 12 & $\begin{array}{l}\gamma_{N} \\
10 \mu \mathrm{m}\end{array}$ & $1240 \mathrm{HV}_{0.01}$ & (Dong et al., 2006) \\
\hline AISI 316L & $\begin{array}{l}600 \mathrm{~Pa} \\
\mathrm{~N}_{2}: \mathrm{H}_{2} 1: 4\end{array}$ & 400 & $2-7$ & $\begin{array}{l}\gamma_{N}+y^{\prime}-\mathrm{Fe}_{4} \mathrm{~N}+\varepsilon-\mathrm{Fe}_{2,3} \mathrm{~N}+\mathrm{CrN}+\mathrm{Cr}_{2} \mathrm{~N} \\
8 \mu \mathrm{m}\end{array}$ & - & (Olzon-Dionysio et al., 2008) \\
\hline AISI 316L & $\begin{array}{l}600 \mathrm{~Pa} \\
\mathrm{~N}_{2}: \mathrm{H}_{2} 1: 4\end{array}$ & 400 & $2-7$ & $\begin{array}{l}\gamma_{N}+y^{\prime}-\mathrm{Fe}_{4} \mathrm{~N}+\mathrm{CrN} \\
6 \mu \mathrm{m}\end{array}$ & - & (de Souza et al., 2010) \\
\hline AISI 410 & $\begin{array}{l}500 \mathrm{~Pa} \\
\mathrm{~N}_{2}: \mathrm{H}_{2} 1: 3\end{array}$ & $240-500$ & 20 & $\begin{array}{l}\gamma^{\prime}-\mathrm{Fe}_{4} \mathrm{~N}+\varepsilon-\mathrm{Fe}_{2,3} \mathrm{~N}+\mathrm{CrN}+\mathrm{a}_{\mathrm{N}} \\
47-135 \mu \mathrm{m} \\
\mathrm{CD}: 77-186 \mu \mathrm{m}\end{array}$ & $1000-1200 H_{0.1}$ & (Li and Bell, 2006) \\
\hline AISI 420 & $\begin{array}{l}650 \mathrm{~Pa} \\
\mathrm{~N}_{2}: \mathrm{H}_{2} 1: 3\end{array}$ & 300 & 20 & $\gamma^{\prime}-\mathrm{Fe}_{4} \mathrm{~N}+\varepsilon-\mathrm{Fe}_{2,3} \mathrm{~N}+\mathrm{CrN}$ & - & (Tuckart et al., 2007) \\
\hline AISI 420 & $\begin{array}{l}300-400 \mathrm{~Pa} \\
\mathrm{~N}_{2}: \mathrm{H}_{2} 1: 4\end{array}$ & 530 & 20 & $\begin{array}{l}\gamma^{\prime}-\mathrm{Fe}_{4} \mathrm{~N}+\varepsilon-\mathrm{Fe}_{3} \mathrm{~N}+\mathrm{CrN} \\
\mathrm{CD}: 61 \mu \mathrm{m}\end{array}$ & $1300 \mathrm{HV}_{0.1}$ & (Alphonsa et al., 2002) \\
\hline AISI 4340 & $\mathrm{NH}_{3}$ & $500-540$ & $2-16$ & $\begin{array}{l}\gamma^{\prime}-\mathrm{Fe}_{4} \mathrm{~N}+\varepsilon-\mathrm{Fe}_{3} \mathrm{~N} 2.6-8.8 \mu \mathrm{m} \\
\mathrm{CD}: 280-510 \mu \mathrm{m}\end{array}$ & $500-640 \mathrm{HV}_{0.2}$ & (Sirin et al., 2008; Sirin and Kaluc, 2012) \\
\hline AISI CA6NM & $\begin{array}{l}400 \mathrm{~Pa} \\
\mathrm{~N}_{2}: \mathrm{H}_{2} 1: 4\end{array}$ & 500 & $1-5$ & $\begin{array}{l}\mathrm{Y}^{\prime}-\mathrm{Fe}_{4} \mathrm{~N}+\varepsilon-\mathrm{Fe}_{2,3} \mathrm{~N}+\mathrm{CrN} \\
2-6 \mu \mathrm{m}\end{array}$ & $1245-1309 \mathrm{HV}_{0.05}$ & (Winck et al., 2013) \\
\hline AISI H12 & $\begin{array}{l}600 \mathrm{~Pa} \\
\mathrm{~N}_{2}: \mathrm{H}_{2} 1: 4\end{array}$ & 500 & $1-6$ & $\begin{array}{l}\mathrm{Y}^{\prime}-\mathrm{Fe}_{4} \mathrm{~N}+\varepsilon-\mathrm{Fe}_{2,3} \mathrm{~N}+\mathrm{a}^{\prime \prime}-\mathrm{Fe}_{16} \mathrm{~N}_{2} \\
\mathrm{CD}: 38-85 \mu \mathrm{m}\end{array}$ & $1240 \mathrm{HV}_{70 \mathrm{gf}}$ & (Miola et al., 1999) \\
\hline AISI HNV3 & $\mathrm{N}_{2}: \mathrm{H}_{2}$ & $450-650$ & $3-6$ & - & 5.39-13.14 GPa & (Sobiecki et al., 2004) \\
\hline $\mathrm{HP} 13 \mathrm{Cr}$ & $\begin{array}{l}300 \mathrm{~Pa} \\
\mathrm{~N}_{2}: \mathrm{H}_{2} 1: 4\end{array}$ & $350-450$ & 6 & $\begin{array}{l}\mathrm{Y}^{\prime}-\mathrm{Fe}_{4} \mathrm{~N}+\varepsilon-\mathrm{Fe}_{2+\times} \mathrm{N}+\mathrm{CrN}+\mathrm{a}_{N} \\
\mathrm{CD}: 16-61 \mu \mathrm{m}\end{array}$ & $12-14 \mathrm{GPa}$ & (Kurelo et al., 2015) \\
\hline UNS S31254 & $\begin{array}{l}500 \mathrm{~Pa} \\
\mathrm{~N}_{2}: \mathrm{H}_{2} 1: 4\end{array}$ & $400-500$ & 5 & $\begin{array}{l}\mathrm{YN}_{\mathrm{N}}+\mathrm{CrN}+\mathrm{Cr}_{2} \mathrm{~N} \\
10 \mu \mathrm{m}\end{array}$ & $980-1380 \mathrm{HV}_{0.025}$ & (Fernandes et al., 2010) \\
\hline
\end{tabular}


Tab. 2. Data on pulsed direct current plasma nitriding collected from the literature; $C D$ - case depth

\begin{tabular}{|c|c|c|c|c|c|c|}
\hline Material & Parameters & Temp. $\left({ }^{\circ} \mathrm{C}\right)$ & Time $(\mathrm{h})$ & Nitride layer characteristics & Hardness & Ref. \\
\hline AISI 2205 & $\begin{array}{l}300 \mathrm{~Pa} \\
\mathrm{~N}_{2}: \mathrm{H}_{2}: \mathrm{Ar} 4-8: 1-3: 1-3\end{array}$ & $250-500$ & $8-60$ & $\begin{array}{l}\gamma_{N}+y^{\prime}-\mathrm{Fe}_{4} \mathrm{~N}+\mathrm{CrN} \\
1.7 \mu \mathrm{m}\end{array}$ & 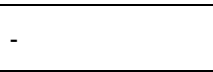 & (Larisch et al., 1999) \\
\hline AISI 2205 & $\begin{array}{l}250 \mathrm{~Pa} \\
\mathrm{~N}_{2}: \mathrm{H}_{2} 2: 1\end{array}$ & 400 & 20 & $\begin{array}{l}y^{\prime}-\mathrm{Fe}_{4} \mathrm{~N}+\varepsilon-\mathrm{Fe}_{3} \mathrm{~N}+\mathrm{CrN} \\
12 \mu \mathrm{m}\end{array}$ & $1420-1960 \mathrm{HV}_{0.01}$ & (Kliauga and Pohl, 1998) \\
\hline AISI 304 & $\begin{array}{l}300 \mathrm{~Pa} \\
\mathrm{NH}_{3}\end{array}$ & $350-540$ & 4 & $\gamma_{N}+\gamma^{\prime}-\mathrm{Fe}_{4} \mathrm{~N}+\mathrm{CrN} 2-12 \mu \mathrm{m}$ & $3-14.7 \mathrm{GPa}$ & (Liang, 2003) \\
\hline AISI 304 & $\begin{array}{l}400 \mathrm{~Pa} \\
\mathrm{~N}_{2}: \mathrm{H}_{2} 1: 4\end{array}$ & 560 & 24 & $\begin{array}{l}\mathrm{Y}^{\prime}-\mathrm{Fe}_{4} \mathrm{~N}+\varepsilon-\mathrm{Fe}_{3} \mathrm{~N}+\mathrm{CrN} \\
\mathrm{CD}: 40-90 \mu \mathrm{m}\end{array}$ & $900-1100 \mathrm{HV}_{0.1}$ & (Singh et al., 2006) \\
\hline AISI 304 & $\begin{array}{l}400 \mathrm{~Pa} \\
\mathrm{~N}_{2}: \mathrm{H}_{2} 4: 1\end{array}$ & 560 & 24 & $\begin{array}{l}Y^{\prime}-\mathrm{Fe}_{4} \mathrm{~N}+\varepsilon-\mathrm{Fe}_{3} \mathrm{~N}+\mathrm{CrN} \\
\mathrm{CD}: 50-110 \mu \mathrm{m}\end{array}$ & $1000-1300 \mathrm{HV}_{0.1}$ & (Singh et al., 2006) \\
\hline AISI 304 & $\begin{array}{l}250 \mathrm{~Pa} \\
\mathrm{~N}_{2}: \mathrm{H}_{2} 1: 2\end{array}$ & - & - & $\begin{array}{l}\mathrm{N}+\mathrm{CrN} \\
\mathrm{CD}: 22 \mu \mathrm{m}\end{array}$ & & (Michler, 2008) \\
\hline AISI 304L & $\begin{array}{l}600 \mathrm{~Pa} \\
\mathrm{~N}_{2}: \mathrm{H}_{2} 1: 4\end{array}$ & 450 & $1 / 2-16$ & $y_{N}+C r N$ & $1500-1600 \mathrm{HK}_{0.01}$ & (Menthe and Rie, 1999) \\
\hline AISI 316L & $\begin{array}{l}250 \mathrm{~Pa} \\
\mathrm{~N}_{2}: \mathrm{H}_{2} 1: 3\end{array}$ & $400-550$ & 12 & $\gamma_{N}+\gamma^{\prime}-\mathrm{Fe}_{4} \mathrm{~N}+\varepsilon-\mathrm{Fe}_{2,3} \mathrm{~N}+\mathrm{CrN}+\mathrm{Cr}_{2} \mathrm{~N}$ & $1450-1500 \mathrm{HV}_{0.025}$ & (Mingolo et al., 2006) \\
\hline AISI 316L & $\begin{array}{l}250 \mathrm{~Pa} \\
\mathrm{~N}_{2}: \mathrm{H}_{2} 3: 1\end{array}$ & $400-550$ & 12 & $\gamma_{N}+\gamma^{\prime}-\mathrm{Fe}_{4} \mathrm{~N}+\varepsilon-\mathrm{Fe}_{2,3} \mathrm{~N}+\mathrm{CrN}+\mathrm{Cr}_{2} \mathrm{~N}$ & $1400-1500 \mathrm{HV}_{0.025}$ & (Mingolo et al., 2006) \\
\hline AISI 316L & $\begin{array}{l}173 \mathrm{~Pa} \\
\mathrm{~N}_{2}: \mathrm{H}_{2} 1: 1\end{array}$ & 400 & - & $\begin{array}{l}\gamma_{N} \\
3.4-4.8 \mu \mathrm{m}\end{array}$ & $1245 \mathrm{HV}_{0.025}$ & (Díaz-Guillén et al., 2015) \\
\hline AISI 316L & $\begin{array}{l}533 \mathrm{~Pa} \\
\mathrm{~N}_{2}: \mathrm{H}_{2} 4: 1\end{array}$ & $400-500$ & 5 & $\begin{array}{l}Y_{N}+y^{\prime}-\mathrm{Fe}_{4} \mathrm{~N}+\mathrm{CrN} \\
5-70 \mu \mathrm{m}\end{array}$ & $1115-1315 \mathrm{HV}_{0.1}$ & (Jeong and Kim, 2001) \\
\hline AISI 321 & $\begin{array}{l}300 \mathrm{~Pa} \\
\mathrm{~N}_{2}: \mathrm{H}_{2}: \mathrm{Ar} 4-8: 1-3: 1-3\end{array}$ & $250-500$ & $8-60$ & $\gamma_{N}+\gamma^{\prime}-\mathrm{Fe}_{4} \mathrm{~N}+\mathrm{CrN} 2.5 \mu \mathrm{m}$ & $3305-8292 \mathrm{HV}_{0.0001}$ & (Larisch et al., 1999) \\
\hline AISI 410 & $\begin{array}{l}600 \mathrm{~Pa} \\
\mathrm{~N}_{2}: \mathrm{H}_{2} 1: 3\end{array}$ & $350-500$ & $20-28$ & $\begin{array}{l}\gamma^{\prime}-\mathrm{Fe}_{4} \mathrm{~N}+\varepsilon-\mathrm{Fe}_{2,3} \mathrm{~N}+\mathrm{CrN}+\mathrm{a}_{\mathrm{N}} \\
\mathrm{CD}: 30 \mu \mathrm{m}\end{array}$ & $1150-1400 \mathrm{HV}_{0.025}$ & (Corengia et al., 2004b) \\
\hline AISI 420 & $\begin{array}{l}600 \mathrm{~Pa} \\
\mathrm{~N}_{2}: \mathrm{H}_{2} 1: 3\end{array}$ & $350-550$ & 15 & $\begin{array}{l}\varepsilon-F e_{3} N+\gamma^{\prime}-F_{4} N+a_{N} \\
C D: 90-130 \mu m\end{array}$ & $1000-1200 \mathrm{HK}_{0.025}$ & (Xi et al., 2008a; Xi et al., 2008b) \\
\hline AISI 420 & $\begin{array}{l}250 \mathrm{~Pa} \\
\mathrm{~N}_{2}: \mathrm{H}_{2} 3: 1\end{array}$ & $480-560$ & 4 & $\begin{array}{l}y^{\prime}-\mathrm{Fe}_{4} \mathrm{~N}+\varepsilon-\mathrm{Fe}_{2,3} \mathrm{~N}+\mathrm{CrN} \\
\mathrm{CD}: 80 \mu \mathrm{m}\end{array}$ & $1525 \mathrm{HV}_{0.025}$ & (Pinedo and Monteiro, 2004) \\
\hline AISI 430 & $\begin{array}{l}300 \mathrm{~Pa} \\
\mathrm{~N}_{2}: \mathrm{H}_{2}: \operatorname{Ar} 4-8: 1-3: 1-3\end{array}$ & $250-500$ & $8-60$ & $\begin{array}{l}\gamma_{N}+\gamma^{\prime}-\mathrm{Fe}_{4} \mathrm{~N}+\varepsilon-\mathrm{Fe}_{2,3} \mathrm{~N}+\mathrm{CrN} \\
14.6 \mu \mathrm{m}\end{array}$ & - & (Larisch et al., 1999) \\
\hline AISI 4140 & $\begin{array}{l}500 \mathrm{~Pa} \\
\mathrm{~N}_{2}: \mathrm{H}_{2} 17: 3 \\
\end{array}$ & $570-620$ & 5 & $\begin{array}{l}\gamma^{\prime}-\mathrm{Fe}_{4} \mathrm{~N}+\varepsilon-\mathrm{Fe}_{2,3} \mathrm{~N} \\
\mathrm{CD}: 42 \mu \mathrm{m}\end{array}$ & - & (Fattah and Mahboubi, 2010) \\
\hline AISI 4140 & $\begin{array}{l}600 \mathrm{~Pa} \\
\mathrm{~N}_{2}: \mathrm{H}_{2} 1: 3\end{array}$ & 500 & $2-28$ & $\begin{array}{l}\mathrm{Y}^{\prime}-\mathrm{Fe}_{4} \mathrm{~N}+\varepsilon-\mathrm{Fe}_{2,3} \mathrm{~N} \\
3-7.5 \mu \mathrm{m} \\
\mathrm{CD}: 220-600 \mu \mathrm{m}\end{array}$ & $650-850 \mathrm{HV}_{0.1}$ & (Corengia et al., 2005) \\
\hline AISI 4340 & $\begin{array}{l}173 \mathrm{~Pa} \\
\mathrm{~N}_{2}: \mathrm{H}_{2} 1: 1\end{array}$ & 540 & 4 & $\begin{array}{l}y^{\prime}-\mathrm{Fe}_{4} \mathrm{~N} \\
7.5-14.5 \mu \mathrm{m} \\
\mathrm{CD}:<350 \mu \mathrm{m}\end{array}$ & $700-825 \mathrm{HV}_{0.05}$ & (Díaz-Guillén et al., 2009) \\
\hline AISI 52100 & $\begin{array}{l}500 \mathrm{~Pa} \\
\mathrm{~N}_{2}: \mathrm{H}_{2} 7: 13\end{array}$ & $450-560$ & $1-5$ & $\varepsilon-\mathrm{Fe}_{2,3} \mathrm{~N}+\mathrm{y}^{\prime}-\mathrm{Fe}_{4} \mathrm{~N}$ & - & (Basu et al., 2008) \\
\hline AISI CA6NM & $\begin{array}{l}532 \mathrm{~Pa} \\
\mathrm{~N}_{2}: \mathrm{H}_{2} 1: 4\end{array}$ & 500 & 2 & $\begin{array}{l}\gamma^{\prime}-\mathrm{Fe}_{4} \mathrm{~N}+\varepsilon-\mathrm{Fe}_{2,3} \mathrm{~N}+\mathrm{CrN} \\
\mathrm{CD}: 25 \mu \mathrm{m}\end{array}$ & $1240 \mathrm{HV}_{0.5}$ & (Allenstein et al., 2013) \\
\hline AISI H12 & $\begin{array}{l}600 \mathrm{~Pa} \\
\mathrm{~N}_{2}: \mathrm{H}_{2} 1: 4\end{array}$ & 500 & $1-6$ & $\gamma^{\prime}-\mathrm{Fe}_{4} \mathrm{~N}+\varepsilon-\mathrm{Fe}_{2,3} \mathrm{~N}+\mathrm{a}^{\prime \prime}-\mathrm{Fe}_{16} \mathrm{~N}_{2}$ & - & (Miola et al., 1999) \\
\hline AISI L2 & $\begin{array}{l}666 \mathrm{~Pa} \\
\mathrm{~N}_{2}: \mathrm{H}_{2} 3: 7\end{array}$ & $450-550$ & $6-9$ & $\begin{array}{l}y^{\prime}-\mathrm{Fe}_{4} \mathrm{~N}+\varepsilon-\mathrm{Fe}_{3} \mathrm{~N} \\
\mathrm{CD}: 110-330 \mu \mathrm{m}\end{array}$ & $480-510 \mathrm{HV}_{0.02}$ & (Soleimani et al., 2012) \\
\hline AISI M2 & $\begin{array}{l}400 \mathrm{~Pa} \\
\mathrm{~N}_{2}: \mathrm{H}_{2} 4: 1\end{array}$ & $50-570$ & 5 & $4-6 \mu \mathrm{m}$ & - & (Jeong and Kim, 2001) \\
\hline AISI P21 & $\begin{array}{l}600 \mathrm{~Pa} \\
\mathrm{~N}_{2}: \mathrm{H}_{2} 1: 3 \\
\end{array}$ & $475-525$ & 10 & $\begin{array}{l}y^{\prime}-\mathrm{Fe}_{4} \mathrm{~N}+\varepsilon-\mathrm{Fe}_{2,3} \mathrm{~N} 2.8-5 \mu \mathrm{m} \\
\mathrm{CD}: 100-200 \mu \mathrm{m}\end{array}$ & $640-710 \mathrm{HV}_{0.05}$ & (Wen, 2009) \\
\hline Corrax & $\mathrm{N}_{2}: \mathrm{H}_{2} 1: 4$ & 360 & 10 & $\begin{array}{l}Y_{N} \\
10-12 \mu \mathrm{m}\end{array}$ & $1290 \mathrm{HV}_{0.05}$ & (Brühl et al., 2010) \\
\hline M340 & $\mathrm{N}_{2}: \mathrm{H}_{2} 1: 4$ & 360 & 10 & $\begin{array}{l}\mathrm{VN}_{\mathrm{N}}+\mathrm{CrN}+\mathrm{M}_{23} \mathrm{C}_{6} \\
9-10 \mu \mathrm{m}\end{array}$ & $1100 \mathrm{HV}_{0.05}$ & (Brühl et al., 2010) \\
\hline N695 & $\mathrm{N}_{2}: \mathrm{H}_{2} 1: 4$ & 360 & 10 & $\begin{array}{l}\mathrm{VN}_{\mathrm{N}}+\mathrm{CrN}+\mathrm{M}_{23} \mathrm{C}_{6} \\
14-15 \mu \mathrm{m}\end{array}$ & $1130 \mathrm{HV}_{0.05}$ & (Brühl et al., 2010) \\
\hline
\end{tabular}

Because of the different unit cell parameters of the cited $y^{\prime}$ and $\varepsilon$ phases, the mixture of crystalline structures can generate stress at the boundaries of the grains, increasing the fragility of the layer (Sirin and Kaluc, 2012). Delayed cracking of the nitride layers on AISI 420 martensitic stainless steel has been reported by Tuckart et al. (2007). After 24 months incubation time, without any external disturbance, the cracks were formed in the nitrided specimens. According to O'Brien and Goodman (1991), the weak bonding at the interphases or different thermal expansion coefficients of the phases can be the cause of this phenomena.
In the plasma nitrided workpieces, beneath the compound layer, the diffusion layer is formed. The diffusion layer consists mainly of interstitial atoms in solid solution and fine and coherent nitride precipitates (Sirin and Kaluc, 2012; Mashreghi, 2013). The hardness and wear resistance of the diffusion layer depends on the time and temperature of the treatment, the gaseous mixture composition, the concentration of the alloying elements on the steel, the amount of precipitated nitrides and the initial microstructure of the material (Sirin and Kaluc, 2012). In order to determine the nitrogen influence depth, the effective depth case 
is measured (Tab. 1, CD). It is the thickness of the hardened layer of a specimen, understood as the depth up to a further point for which a specified level of hardness is maintained. As can be seen in Tab. 1, in the case of ion nitrided materials, the layer thickness is not identical as the effective depth case.

The mechanisms of conventional DC plasma nitriding have been extensively studied and discussed by many authors, but the consensus has not been reached up to date. The dominant mechanisms for nitrogen mass transfer are claimed to be: nitrogen implantation (Xu and Zhang, 1986), low energetic $\mathrm{NmH}_{\mathrm{n}}{ }^{+}$ bombardment (Hudis, 1973), nitrogen adsorption (Tibbetts, 1974), neutral and ion adsorption (Szabo and Wilhelmi, 1984).

According to Zlatanowić and Popović (2010), a significant advance in plasma surface engineering, as well as in control and stability of the processing, was provided with introduction of pulsed DC power supply in plasma deposition techniques. In pulsed DC supply, the number of parameters which determine the quality of obtained surface, process characteristics and operating procedure is greater than in conventional DC process. Properties of the surface are directly affected by the power supply pulse frequency, duty cycle and output voltage, while the process stability and control are significantly improved (Zlatanowić and Popović, 2010). Pye (2003) claims that in plasma nitriding systems, the DC supply power is adjusted as required to the component geometry and chamber configuration. In conventional DC plasma nitriding technique, it is difficult to provide proper process temperature when the user has a mixed load of different part geometries and sizes. The pulsed technique enables operator adaption of the minimum power input necessary for the abnormal glow discharge (Pye, 2003).

\section{INFLUENCE ON PERFORMANCE OF FERROUS MATERIALS}

The influence of DC and pulsed DC plasma nitriding on ferrous materials performance has been extensively described in numerous studies. In this paper, the effect of ion nitriding on corrosion resistance, as well as on wear and fatigue, will be described.

\subsection{Corrosion resistance}

In recent years, many studies have been performed in order to improve corrosion resistance of austenitic stainless steels by ion nitriding and extend its industrial applications. In contrast, relatively few studies have been conducted so far on low temperature plasma nitriding of martensitic and supermartensitic stainless steels.

In general, many authors have been very positive about the influence of ion nitriding on corrosion resistance of austenitic and superaustenitic steels. In the research by Fossati et al. (2006a; b) it has been stated that the anodic current density in potentiodynamic scans becomes smaller with increase of nitriding treatment time. The authors pointed that in comparison with the untreated samples, the modified AISI 316 L is less prone to pitting corrosion. According to the researchers, the repassivation capability of stainless steels is enhanced with $\gamma_{\mathrm{N}}$ formation due to its high nitrogen concentration. Moreover, in the study by Borgioli et al. (2006) it has been proven that the treatment pressure has a significant influence on performance of AISI $316 \mathrm{~L}$ steel in $5 \% \mathrm{NaCl}$ aerated solution. If the pressure exceeds $1.5 \mathrm{hPa}$, the chromium nitride precipitates or, if the pressure is extremely high $(2.5 \mathrm{hPa})$, treated samples are unable to form homogenous protective passive layer. In addition, Olzon-Dionysio et al. (2008) demonstrated that treatment time pays an important role for the corrosion resistance. According to the authors, the higher the $\varepsilon / y^{\prime}$ ratio, the better. Similar findings were obtained by de Souza et al. (2010). Fernandes et al. (2010) reported that plasma nitriding is beneficial also for UNS S31254 superaustenitic stainless steel, regardless of the process temperature ranging from 400 to $500^{\circ} \mathrm{C}$.

As mentioned before, plasma nitriding process of austenitic stainless steels is conducted in temperatures below $420^{\circ} \mathrm{C}$ in order to prevent the chromium nitrides precipitation. It is believed that formation of $\gamma_{N}$ phase with enough thickness depends on the temperature $\left(<480^{\circ} \mathrm{C}\right)$ and duration of the process ( $\mathrm{Li}$ et al., 2014a). In study by Li et al. (Li et al., 2014a) nitriding of austenitic AISI $316 \mathrm{~L}$ steel was carried out at high temperatures $\left(520-560^{\circ} \mathrm{C}\right)$ for times ranging from 5 to $120 \mathrm{~min}$. Although the layers obtained in the research consisted of $\gamma_{N}$ and a small amount of $\mathrm{CrN}$ and iron nitrides, the pitting corrosion resistance of substrate material has been improved even after 5 minutes of treatment.

Nevertheless, there are also some critical voices on performance of ion nitrided austenitic stainless steels. In the electrochemical impedance spectroscopy study by Borowski et al. (2010) it was exhibited that impedance of DC nitrided specimen was reduced by two orders of magnitude with respect to the untreated material. What is more, the polarization curves exhibited that DC nitriding of AISI 316L resulted in increase of corrosion current and shift of corrosion potential towards less noble materials. Liang (2003) reported that nitriding of AISI 304 steel only in temperatures below $450^{\circ} \mathrm{C}$ resulted in improvement in corrosion resistance, especially pitting corrosion. Samples nitrided at $465^{\circ} \mathrm{C}$ exhibited poor corrosion resistance, having lower corrosion potential and higher corrosion current density compared to the untreated specimens. In research by Liang et al. (2001) the DC plasma nitrided AISI 304 steel was characterized by low corrosion potential and very high corrosion current density $\left(7.15 \mu \mathrm{A} \times \mathrm{cm}^{-2}\right)$, indicating high dissolution rates. As authors suggested, low pressure plasma arc source nitriding provided better substrate material performance than DC nitriding. Reduced corrosion resistance of PN AISI 316L stainless steel has also been reported by Karimzadeh et al. (2013). Inferior corrosion resistance has been attributed to the existence of sliding bands, created as a consequence of $\gamma_{\mathrm{N}}$ formation. According to the authors, the mentioned sliding bands can provide active sites for corrosion processes development. Menthe et al. (1995) stated that the passive layer obtained in the nitriding process is similar to the one naturally existing on AISI $304 \mathrm{~L}$ steel by the means of corrosion resistance. Thus, the corrosion performance is not severely affected by surface modification. The corrosion performance of AISI 316L DC nitrided steel did not significantly improve in comparison with the untreated material in the study by Skolek-Stefaniszyn et al. (2010).

In terms of enhancing corrosion resistance, DC and pulsed DC plasma nitriding seems much more efficient when applied on martensitic, supermartensitic and bearing steels. Li and Bell (2006) demonstrated that the corrosion resistance of AISI 410 steel significantly improved after direct current plasma nitriding; in potentiodynamic tests in $3,5 \% \mathrm{NaCl}_{\text {aq }}$, the passivation region occurred only for nitrided samples. What is more, the pitting potential of surface modified specimens shifted towards positive potentials. The nitrided samples exhibited also lower weight loss in immersion tests in $1 \% \mathrm{HCl}$ solution than untreated material. The 
authors claim that superior corrosion resistance of ion nitrided AISI 410 steel was due to $\varepsilon$ and $y^{\prime}$ iron nitrides precipitation on the material surface. In the research by Corengia et al. (2004b) the positive influence of plasma nitriding on martensitic stainless steels has been proven. However, the authors pointed that samples nitrided for $20 \mathrm{~h}$ in 400 and $500^{\circ} \mathrm{C}$ exhibited decrease in corrosion resistance. Similar findings were obtained by $\mathrm{Xi}$ et al. (2008a) for DC-pulsed nitrided AISI 420 steel. The improvement in corrosion resistance was observed for samples treated in $350^{\circ} \mathrm{C}$. According to the authors, the beneficial effect could be related to the solid solution of $\mathrm{Cr}$ and the $\varepsilon$ and $\mathrm{a}_{\mathrm{N}}$ phases present in the outer layer. However, corrosion resistance of specimens nitrided in 450 and $550^{\circ} \mathrm{C}$ has been reduced due to $\mathrm{CrN}$ formation and $\mathrm{Cr}$ depletion in the solid solution. In other study by these authors (Xi et al., 2008b), resistance to erosion and erosion-corrosion of AISI 420 steel has been examined. According to the results, in both neutral and acidic environment, the erosion-corrosion resistance of investigated steel was improved by means of $350^{\circ} \mathrm{C}$ nitriding, but decreased through $550^{\circ} \mathrm{C}$ nitriding for reasons provided earlier in the text. Basu et al. (2008) observed significant improve in corrosion properties of plasma nitrided AISI 52100 bearing steel. The authors attribute good corrosion resistance in aqueous medium to presence of $\varepsilon$ and $\gamma^{\prime}$ nitrides in the modified layer. The higher temperature and longer time of nitriding process, the greater volume of nitride fraction at the surface.

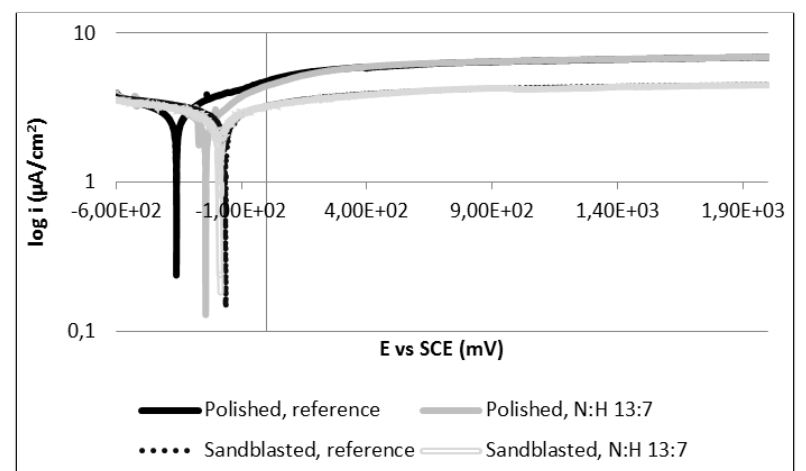

Fig. 1. Potentiodynamic curves of DC plasma nitrided $\left(\mathrm{N}_{2}: \mathrm{H}_{2} 13: 7\right.$, $400^{\circ} \mathrm{C}, 200 \mathrm{~Pa}, 2 \mathrm{~h}$ ) and reference specimens

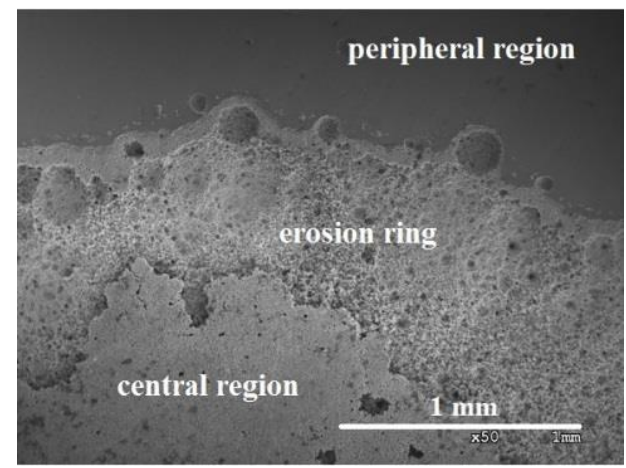

Fig. 2. Corroded surface morphology of DC plasma nitrided specimen, $35 \% \mathrm{H}_{2}: 65 \% \mathrm{~N}_{2}$, SEM photograph, magnification $50 \times$

Negative effect of ion nitriding on corrosion performance of martensitic stainless steels was observed by some authors. In research by Wierzchoń et al. (2006), AISI 420F steel nitrided in $530^{\circ} \mathrm{C}$ in the glow discharge assisted process exhibited slight decrease in corrosion resistance. Potentiodynamic curves of DC nitrided AISI 410 steel presented by Sobiecki et al. (2004) unequivocally indicate reduction in corrosion resistance of material treated in temperatures exceeding $450^{\circ} \mathrm{C}$.

The effect of nitriding on martensitic stainless steel corrosion resistace has also been investigated by the authors of this review. Fig. 1 presents potentiodynamic curves of sandblasted and polished DC plasma nitrided ( $\mathrm{N}_{2}: \mathrm{H}_{2} 13: 7,400^{\circ} \mathrm{C}, 200 \mathrm{~Pa}, 2$ h) AISI $440 \mathrm{~B}$ steel. Taking into account provided results, it may seem that plasma nitriding does not significantly affect corrosion resistance of sandblasted material and slightly improves corrosion properties of polished specimens. Unfortunately, some specimens DC nitrided in slightly different conditions, e.g. nitrogen to hydrogen ratio $7: 13,400^{\circ} \mathrm{C}$ process temperature, $200 \mathrm{~Pa}$ pressure and $2 \mathrm{~h}$ lasting process exhibited severe damages after potentiodynamic tests (Fig. 2).

According to Baldwin et al. (1998), the conventional method of plasma nitriding is effective when nitriding low-alloy or tool steels, but is considered less successful with austenitic stainless or high alloy steels. The process is characterized by some inconvenience especially when workpieces of complex geometry are treated (Olzon-Dionysio et al., 2010). Numerous problems have been encountered arising from the direct plasma applied to the specimens. The reports show that the edge effect, arcing, hollow cathode effect, inhomogeneity of the workpiece temperature are observed (Szilágyiné Biró, 2013), as well as problems with treating parts of different dimensions within one batch (Saeed et al., 2013).

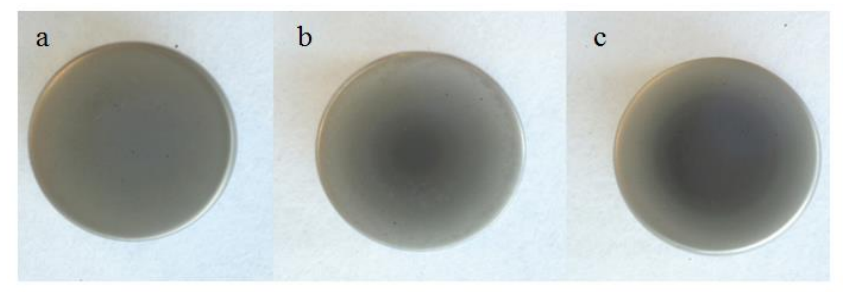

Fig. 3. Plasma nitrided specimens; a - $50 \% \mathrm{H}_{2}: 50 \% \mathrm{~N}_{2}$, b $-35 \% \mathrm{H}_{2}: 65 \% \mathrm{~N}_{2}, \mathrm{c}-20 \% \mathrm{H}_{2}: 80 \% \mathrm{~N}_{2}$; macro photographs (Łępicka i Grądzka-Dahlke, 2013)

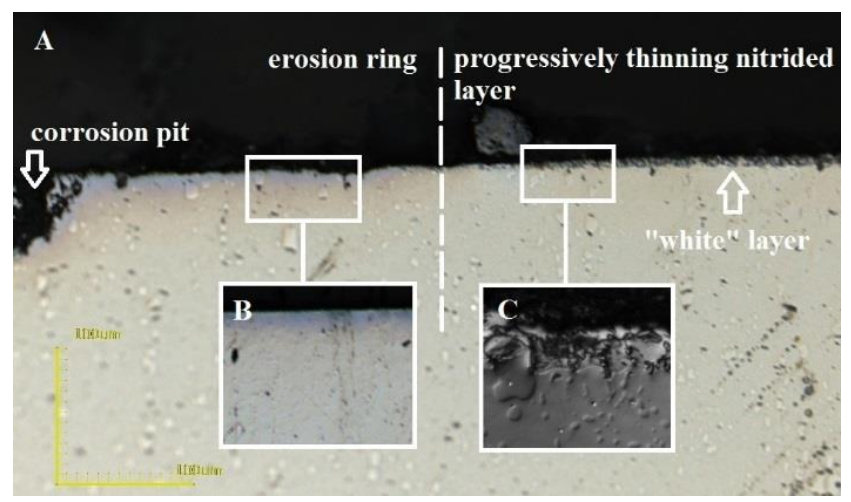

Fig. 4. Cross section of plasma nitrided ( $\left.\mathrm{N}_{2}: \mathrm{H}_{2} 1: 1\right)$ AISI 440B sample after potentiodynamic test. Confocal microscope photograph in: A - 216x, B, C - 2160x magnification

In the edge effect, the nitrogen supersaturated solution is formed on the edges of cylindrical specimens, leading to production of a non-uniform surface with different colors in the central and peripheral regions (Olzon-Dionysio et al., 2010; Szilágyiné Biró, 2013). As mentioned before, in DC plasma nitriding samples 
are submitted to a high cathodic potential and the plasma is produced on their surface. In such case, the distortions in the electric field occur around the corners and the edges of the workload and the shape of the plasma sheath, which determines ion flux distribution, create erosion rings characterized by different colors and discontinuous hardness (Alves Jr. et al., 2001; 2006). The edge effect and its influence on corrosion resistance of stainless steels has also been observed by the authors of this review. Fig. 3 presents DC plasma nitrided AISI 440B specimens in three different gaseous mixture compositions. As it can be seen, the less nitrogen, the smaller the erosion ring. According to Figs. 2 and 4 , the edge effect deteriorates the corrosion resistance of AISI 440B martensitic stainless steel. The affected by the edge effect area becomes the progressively dissolved anode, whereas tightly covered with inhomogenous nitride layer peripheral and central regions act as cathodes (Fig. 4). Detailed results from our studies on influence of DC plasma nitriding on corrosion resistance of AISI 440B martensitic stainless steel can be found in our previous work (Łępicka and Grądzka-Dahlke, 2013; 2014).

The influence of the edge effect on corrosion resistance of stainless steel has also been investigated by Olzon-Dionysio et al. (2010). The AISI 316L samples affected by the edge effect showed poorer corrosion resistance than those without erosion rings. Nevertheless, all investigated specimens exhibited improvement in corrosion resistance with reference to untreated material. According to de Sousa et al. (2014), the edge effect can be eliminated by using cathodic cage ion nitriding.

\subsection{Wear and fatigue}

Phases obtained in the DC and pulsed DC ion nitriding processes $-\gamma_{\mathrm{N}}, \mathrm{Y}^{\prime}-\mathrm{Fe}_{4} \mathrm{~N}$ and $\varepsilon-\mathrm{Fe}_{2,3} \mathrm{~N}-$ are known for their superior hardness and anti-wear properties. In research by Li et al. (2008) the effect of DC plasma nitriding on dry-sliding wear properties of AISI 316L stainless steel has been evaluated. The ring-onblock dry wear test exhibited significant reduction of wear rate in comparison with unnitrided material. It should be noted, however, that the wear rate of nitrided specimens enhanced with increase of treatment temperature, and, as a consequence, $\mathrm{Cr}$ nitrides volume in the modified layer. Wear of the DCPN treated AISI $316 \mathrm{~L}$ steel was dominated by plastic deformation, slight abrasion and frictional polishing. Nevertheless, microcracking of layers with high $\mathrm{CrN}$ content has been observed. Similar findings were obtained by Sun and Bell in ball-on-disc tribosystem (Sun and Bell, 1998) with increasing nitriding temperature, the wear volume of nitrided surface increased. What is more, the higher was nitriding temperature, the greater was friction coefficient. The positive influence of $D C$ ion nitriding on wear resistance of AISI 316L steel has also been noted by Borowski et al. (2010) and Skolek-Stefaniszyn et al. (2010). Foerster et al. (2007) noticed that in dry sliding tests with WC-Co ball as a counter sample glow discharge ion nitriding reduced the friction coefficient with respect to untreated sample. According to Wang et al. (2009), the DC plasma nitriding significantly improves dry-sliding wear resistance also of AISI 304L steel. In the block-on-ring configuration friction test, the minimum value of wear rate was observed for $\mathrm{Y}_{\mathrm{N}}$-rich specimens. As the other authors, Wang et al. (2009) stressed that increasing concentration of $\mathrm{Cr}_{x} \mathrm{~N}$ in the reaction layer results in decrease in drysliding wear resistance. Reduction of AISI 304L wear rate after nitriding was also emphasized by Menthe et al. (2000).

A significant advance in wear rate was also observed in mar- tensitic, duplex, tool and precipitation hardenable steels.

Xi et al. (2008a) conducted dry ball-on-disc tests on AISI 420 steel nitrided in 350 and $550^{\circ} \mathrm{C}$. According to the authors, the antiwear properties of material nitrided in lower temperature overachieve the $550^{\circ} \mathrm{C}$ ones. After nitriding the abrasive wear behavior occurred. In other work by the same authors (Xi et al., 2008b) the same data dependency was acknowledged regarding erosion resistance. Sobiecki et al. (2004) stated that glow-discharge assisted nitriding conducted in temperatures ranging from 450 to $650^{\circ} \mathrm{C}$ remarkably improved frictional wear resistance of AISI HNV3 steel. The harder the surface, the better the anti-wear properties. Similar conclusions were obtained by Kliauga and Pohl (1998) for ion nitrided AISI F51 duplex steel. In research by Wen (2009) friction- and wear tests of AISI P21 DC nitrided steel were conducted under dry conditions on a block-on-ring tribotester. A significant reduction in the wear and friction coefficient was observed. As the author noticed, greater compressive stress and higher hardness of the nitrided specimen translates into its better wear resistance. The anti-wear properties of investigated steel were related to the increase in the thickness of diffusion layer.

Fatigue strength study of AISI 4340 steel conducted by Sirin et al. (2008) demonstrated that in comparison with untreated steel the fatigue strength of nitrided material increased up to $91 \%$. A linear relationship between the case depth and the fatigue strength was obtained. The fatigue behavior after ion nitriding was also observed for AISI L2 cold work tool steel by Soleimani et al. (2012). The fatigue strength of nitrided in $550^{\circ} \mathrm{C}$ for $6 \mathrm{~h}$ samples improved by about $67 \%$. As in research by Sirin et al. (2008) the dominant fatigue crack initiation mechanism was subsurface "fish eye" type crack formation which originated from nonmetallic inclusions.

The beneficial influence of plasma nitriding on fatigue limit of ferrous materials was also reported by Winck et al. (2013). According to the authors, after just $1 \mathrm{~h}$ of nitriding in $500^{\circ} \mathrm{C}$ the fatigue life of CA6NM type steel increased by $23.67 \%$ at 2 million cycles. Fractographic analysis of fracture surfaces showed that the fractured surfaces resembled the structure referred to as "fish eye".

Additionally, the researchers stated that in low stress level (250 MPa) fatigue tests, the fatigue life of nitrided AISI 304L steel is raised by a factor of 10 .

However, there are also studies concerning negative effect of plasma nitriding on fatigue life of austenitic steels. In research by Raman and Jayaprakash (2007) the plasma nitrided AISI 304 exhibited inferior plain fatigue and fretting fatigue lives compared with the unmodified material. As the authors claim, this was caused by chromium segregation at the grains boundaries of ion nitrided specimens. The chromium nitrides precipitation might have weakened the grain boundaries, resulting in early crack initiation and its accelerated propagation.

\subsection{Direct Current Plasma Nitriding: other shortcomings}

As mentioned in the previous paragraphs, beside the edge effect, DC plasma nitriding is characterized also by inconvenience as arcing and hollow cathode effect.

Arcing, caused mainly by degassing in localized area of the specimen surface, leads to local heat up of the part to extreme temperatures and, as an effect, melting or sputtering material from its surface (Szilágyiné Biró, 2013). Severe arcing of the component results in necessity of scraping the metallic part. In order to 
prevent arcing, the batch must be thoroughly cleaned from oil, grease and rust in relatively expensive cleaning routine (Gallo and Dong, 2009). According to Sharma et al. (2006) arcing can also be avoided by optimizing duty factor of the pulse in plasma deposition method.

The hollow cathode effect occurs when nitrided parts are of complex shape or contain deep holes, especially the blind ones (Szilágyiné Biró, 2013). During the ionization process, the gas is trapped in the hollow cavities and immobilized. This causes local heating of the product and can result in structure or property changes that affect the part's performance in service (Szilágyiné Biró, 2013). Soltani Asadi and Mahboubi (Soltaniet al., 2012) have conducted research in which the effect of the sample geometry on the DC plasma nitrided steel was investigated. According to the authors, the hollow cathode effect was observed at the sample with $2 \mathrm{~mm}$ width groove. The microhardness tests results revealed that the sample was overheated during the plasma nitriding process, whereas samples with grooves of 4, 6, 8 and $10 \mathrm{~mm}$ width were not overheated. What is more, the hollow cathode effect led to large in size and prone to coursing nitrides formation.

Surprisingly, the hollow cathode effect found its application in variety of plasma processing techniques, e.g. thin film depositions and surface treatment. For example, in the research by Li et al. (2014c) the hollow cathode discharge effect was used to easily heat batch and working space.

In order to avoid described above common problems attributed with DC nitriding, many efforts have been made over past few years to develop high productive plasma nitriding methods. The same type of complex nitrided layer can be produced by numerous nitriding methods, e.g. RF nitriding (Baldwin et al., 1998), plasma immersion ion implantation (Blawert et al., 1998; Saklakoglu et al., 2007), plasma source ion nitriding (Liang et al., 2001), anodic nitriding (Psyllaki et al., 2008), laser nitriding (Psyllaki et al., 2008), cyclic plasma nitriding catalyzed by rare earth metals (We et al., 2010), cathodic cage plasma nitriding (de Sousa et al., 2007; Ribeiro et al., 2008) or nitrogen ion-beam implantation combined with pulsed plasma nitriding (Ochoa et al., 2005). Due to promising results from numerous studies by many researchers, the influence of mentioned nitriding techniques on ferrous materials performance will be described in the next paper.

\section{CONCLUSIONS}

The aim of the review was to provide comprehensive summary on direct current and pulsed direct current plasma nitriding of ferrous materials. Used in a great number of industry branches, ion nitriding is an attractive method that maximizes performance and service life of metallic materials.

According to the results, DC and pulsed DC plasma nitriding is an effective surface hardening, anti-wear and anti-corrosion method applied on austenitic, superaustenitic, martensitic, supermartensitic, duplex, tool, valve, precipitation hardened steels. Nevertheless, there are also well documented cases of deteriorating effect of this surface modification method on tribological and corrosion properties of ferrous materials.

The discussed technique has also its drawbacks, e.g. the edge effect, arcing and hollow cathode effect, which result in inhomogeneity of obtained layer. The occurrence of mentioned disadvantages is virtually impossible to prevent in DC method, especially on small details.

\section{REFERENCES}

1. Allenstein A.N., Lepienski C.M., Buschinelli A.A., Brunatto S.F. (2013), Plasma nitriding using high $\mathrm{H}_{2}$ content gas mixtures for a cavitation erosion resistant steel, Applied Surface Science, Vol. 277, 15-24.

2. Alphonsa I., Chainani A., Raole P.M., Ganguli B., John P.I. (2002), A study of martensitic stainless steel AISI 420 modified using plasma nitriding, Surface and Coatings Technology, Vol. 150, 263268.

3. Alves Jr. C., da Silva E.F., Martinelli A.E. (2001), Effect of workpiece geometry on the uniformity of nitrided layers, Surface and Coatings Technology, Vol. 139, 1-5.

4. Alves Jr. C., de Araújo F.O., Ribeiro K.B., da Costa J.P., Sousa R.M., de Sousa R.S. (2006), Use of cathodic cage in plasma nitriding, Surface and Coatings Technology, Vol. 201, 2450-2454.

5. Baldwin M.J., Fewell M.P., Haydon S.C., Kumar S., Collins G.A., Short K.T., Tendys J. (1998), Rf-plasma nitriding of stainless steel, Surface and Coatings Technology, Vol. 98, 1187-1191.

6. Balusamy T., Sankara Narayanan T.N., Ravichandran K., Park I.S., Lee M.H. (2013), Plasma nitriding of AISI 304 stainless steel: Role of surface mechanical attrition treatment, Materials Characterization, Vol. 85, 38-47.

7. Basu A., Majumdar J.D., Alphonsa J., Mukherjee S., Manna, I. (2008), Corrosion resistance improvement of high carbon low alloy steel by plasma nitriding, Materials Letters, Vol. 62, 3117-3120.

8. Bell T. (2002), Surface engineering of austenitic stainless steel, Surface Engineering, Vol. 18, 415-422.

9. Blawert C., Mordike B.L., Collins G.A., Short K.T., Tendys, J. (1998), Influence of process parameters on the nitriding of steels by plasma immersion ion implantation, Surface and Coatings Technology, Vol. 103-104, 240-247.

10. Borges C.M., Hennecke S., Pfender E. (2000), Decreasing chromium precipitation in AISI 304 stainless steel during the plasmanitriding process, Surface and Coatings Technology, Vol. 123, 112-121.

11. Borgioli F., Fossati A., Galvanetto E., Bacci T. (2005), Glowdischarge nitriding of AISI $316 \mathrm{~L}$ austenitic stainless steel: influence of treatment temperature, Surface and Coatings Technology, Vol. 200, 2474-2480.

12. Borgioli F., Fossati A., Galvanetto E., Bacci T., Pradelli G. (2006), Glow discharge nitriding of AISI 316L austenitic stainless steel: Influence of treatment pressure, Surface and Coatings Technology, Vol. 200, 5505-5513.

13. Borowski T., Kamiński J., Trojanowski J., Wierzchoń T. (2010), Analysis of the structure and properties plasma nitrided $316 \mathrm{~L}$ steel in different zones of plasma discharge (in polish), Archives of Machine Technology and Automatization, Vol. 30, 69-77.

14. Brühl S.P., Charadia R., Simison S., Lamas D.G., Cabo A. (2010), Corrosion behavior of martensitic and precipitation hardening stainless steels treated by plasma nitriding, Surface and Coatings Technology, Vol. 204, 3280-3286.

15. Corengia P., Traverso M.G., García Alonso-García D., Egidi D.A., Ybarra G., Moina C., Cabo A. (2004a), DC-Pulsed plasma nitriding of 4140: microstructure and topography, Matéria, Vol. 9, 111.

16. Corengia P., Ybarra G., Moina C., Cabo A., Broitman E. (2004b), Microstructure and corrosion behaviour of DC-pulsed plasma nitrided AISI 410 martensitic stainless steel, Surface and Coatings Technology, Vol. 187, 63-69.

17. Corengia P., Ybarra G., Moina C., Cabo A., Broitman E. (2005), Microstructural and topographical studies of DC-pulsed plasma nitrided AISI 4140 low-alloy steel, Surface and Coatings Technology, Vol. 200, 2391-2397.

18. de Sousa R.M., de Araújo F.O., Ribeiro K.B., Mendes M.D., da Costa J.P., Alves Jr. C. (2007), Cathodic cage nitriding of 
samples with different dimensions, Materials Science and Engineering A, Vol. 465, 223-227.

19. de Sousa R.M., Moura Y.L., de Sousa P.O., Neto J.M., Costa T.C., Alves Jr. C. (2014), Nitriding of AISI 1020 Steel: Comparison Between Conventional Nitriding and Nitriding with Cathodic Cage, Materials Research, Vol. 17, 708-713.

20. de Souza S.D., Olzon-Dionysio M., Basso R.O., de Souza S. (2010), Mössbauer spectroscopy study on the corrosion resistance of plasma nitrided ASTM F138 stainless steel in chloride solution, Materials Characterization, Vol. 61, 992-999.

21. Díaz-Guillén J.C., Campa-Castilla A., Pérez-Aguilar S.I., GrandaGutiérrez E.E., Garza-Gómez A., Candelas-Ramírez J., MéndezMéndez R. (2009), Effect of duty cycle on surface properties of AISI 4340 using a pulsed plasma nitriding process, Superficies y Vacio, Vol. 22, 1-4.

22. Díaz-Guillén J.C., Granda-Gutiérrez E.E., Vargas-Gutiérrez G., Díaz-Guillén M.R., Aguilar-Martínez J.A., Álvarez-Contreras L. (2015), Effect of Nitriding Current Density on the Surface Properties and Crystallite Size of Pulsed Plasma-Nitrided AISI 316L, Journal of Materials Science and Chemical Engineering, Vol. 3, 45-51.

23. Dong H., Qi P.Y., Li X.Y., Llewellyn R.J. (2006), Improving the erosion-corrosion resistance of AISI 316 austenitic stainless steel by low-temperature plasma surface alloying with $\mathrm{N}$ and $\mathrm{C}$, Materials Science and Engineering A, Vol. 431, 137-145.

24. Fattah M., Mahboubi F. (2010), Comparison of ferritic and austenitic plasma nitriding and nitrocarburizing behavior of AISI 4140 low alloy steel, Materials and Design, Vol. 31, 3915-3921.

25. Fernandes F.P., Heck S.C., Pereira R.G., Picon C.A., Nascente P.P., Casteletti L.C. (2010), lon nitriding of a superaustenitic stainless steel: Wear and corrosion characterization, Surface and Coatings Technology, Vol. 204, 3087-3090.

26. Foerster C.E., Serbena F.C., da Silva S.R., Lepienski C.M., de M. Siqueira C. J., Ueda M. (2007), Mechanical and tribological properties of AISI 304 stainless steel nitrided by glow discharge compared to ion implantation and plasma immersion ion implantation, Nuclear Instruments and Methods in Physics Research B, Vol. 257, 732-736.

27. Fossati A., Borgioli F., Galvanetto E., Bacci T. (2006a), Corrosion resistance properties of glow-discharge nitrided AISI 316L austenitic stainless steel in $\mathrm{NaCl}$ solutions, Corrosion Science, Vol. 48, 15131527.

28. Fossati A., Borgioli F., Galvanetto E., Bacci T. (2006b), Glowdischarge nitriding of AISI 316 L austenitic stainless steel: influence of treatment time, Surface and Coatings Technology, Vol. 200, 35113517.

29. Gallo S.C., Dong H. (2009), Study of active screen plasma processing conditions for carburising and nitriding austenitic stainless steel, Surface and Coatings Technology, Vol. 203, 3669-3675.

30. Hudis M. (1973), Study of ion-nitriding, Journal of Applied Physics, Vol. 44, 1489-1496.

31. Jeong B.Y., Kim M.H. (2001), Effects of pulse frequency and temperature on the nitride layer and surface characteristics of plasma nitrided stainless steel, Surface and Coatings Technology, Vol. 137, 249-254.

32. Jeong B.Y., Kim M.H. (2001), Effects of the process parameters on the layer formation behavior of plasma nitrided steels, Surface and Coatings Technology, Vol. 141, 182-186.

33. Karimzadeh N., Moghaddam E.G., Mirjani M., Raeissi K. (2013), The effect of gas mixture of post-oxidation on structure and corrosion behavior of plasma nitrided AISI 316 stainless steel, Applied Surface Science, Vol. 283, 584-589.

34. Kliauga A.M., Pohl M. (1998), Effect of plasma nitriding on wear and pitting corrosion resistance of X2CrNiMoN22-5-3 duplex stainless steel, Surface and Coatings Technology, Vol. 98, 1205-1210.

35. Kurelo B.E., de Souza G.B., da Silva S.R., Serbena F.C., Foerster C.E., Alves Jr. C. (2015), Plasma nitriding of $\mathrm{HP} 13 \mathrm{Cr}$ supermartensitic stainless steel, Applied Surface Science, Vol. 349, 403-414.
36. Larisch B., Brusky U., Spies H. J. (1999), Plasma nitriding of stainless steels at low temperatures, Surface and Coatings Technology, Vol. 116-119, 205-211.

37. Lępicka M., Grądzka-Dahlke M. (2013), Effect of Heat Treatment and Corrosion Resistance of AISI 440B Martensitic Stainless Steel, Acta Mechanica et Automatica, Vol. 7, 155-159.

38. Łępicka M., Grądzka-Dahlke M. (2014), Effect of Plasma Nitriding Conditions on Corrosion Resistance of AISI 440B Martensitic Stainless Steel, Acta Mechanica et Automatica, Vol. 8, 156-159.

39. Li C.X., Bell T. (2006), Corrosion properties of plasma nitrided AISI 410 martensitic stainless steel in $3.5 \% \mathrm{NaCl}$ and $1 \% \mathrm{HCl}$ aqueous solutions, Corrosion Science, Vol. 48, 2036-2049.

40. Li G.J., Peng Q., Li C., Wang Y., Gao J., Chen S.Y., Shen B.L. (2008), Effect of DC plasma nitriding temperature on microstructure and dry-sliding wear properties of $316 \mathrm{~L}$ stainless steel, Surface and Coatings Technology, Vol. 202, 2749-2754.

41. Li Y., Wang L., Shen L., Zhang D., Wang C. (2010), Plasma nitriding of 42CrMo low alloy steels at anodic or cathodic potentials, Surface and Coatings Technology, Vol. 204, 2337-2342.

42. Li Y., Wang Z., Wang L. (2014a), Surface properties of nitrided layer on AISI 316L austenitic stainless steel produced by high temperature plasma nitriding in short time, Applied Surface Science, Vol. 298, 243-250.

43. Li Y., Xu H., Zhu F., Wang L. (2014b), Low temperature anodic nitriding of AISI 304 austenitic stainless steel, Materials Letters, Vol. 128, 231-234.

44. Li Y., Zhang S., He Y., Zhang L., Wang L. (2014c), Characteristics of the nitrided layer formed on AISI 304 austenitic stainless steel by high temperature nitriding assisted hollow cathode discharge, Materials and Design, Vol. 64, 527-534.

45. Liang W. (2003), Surface modification of AISI 304 austenitic stainless steel by plasma nitriding, Applied Surface Science, Vol. 211, 308-314.

46. Liang W., Juncai S., Xiaolei X. (2001), Low pressure plasma arc source ion nitriding compared with glow-discharge plasma nitriding of stainless steel, Surface and Coatings Technology, Vol. 145, 31-37.

47. Mashreghi A.R., Soleimani S.Y., Saberifar S. (2013), The investigation of wear and corrosion behavior of plasma nitrided DIN 1.2210, Materials and Design, Vol. 46, 532-538.

48. Menthe E., Bulak A., Olfe J., Zimmermann A., Rie K.T. (2000), Improvement of the mechanical properties of austenitic stainless steel after plasma nitriding, Surface and Coatings Technology, Vol. 133-134, 259-263.

49. Menthe E., Rie K.T. (1999), Further investigation of the structure and properties of austenitic stainless steel after plasma nitriding, Surface and Coatings Technology, Vol. 116-119, 199-204.

50. Menthe E., Rie K.T., Schultze J.W., Simson S. (1995), Structure and properties of plasma-nitrided stainless steel, Surface and Coatings Technology, Vol. 74-75, 412-416.

51. Michler T. (2008), Influence of plasma nitriding on hydrogen environment embrittlement of 1.4301 austenitic stainless steel, Surface and Coatings Technology, Vol. 202, 1688-1695.

52. Mingolo N., Tschiptschin A.P., Pinedo C.E. (2006), On the formation of expanded austenite during plasma nitriding of an AISI 316L austenitic stainless steel, Surface and Coatings Technology, Vol. 201, 4215-4218.

53. Miola E.J., de Souza S.D., Olzon-Dionysio M., Spinelli D., dos Santos C.A. (1999), Nitriding of H-12 tool steel by direct-current and pulsed plasmas, Surface and Coatings Technology, Vol. 116-119, 347-351.

54. Musil J., Vlcek J., Ruzicka M. (2000), Recent progress in plasma nitriding, Vacuum, Vol. 59, 940-951.

55. O'Brien J.M., Goodman D. (1991), Heat treating, plasma (ion) nitriding, 240-242, in: Davis W.J.R., Metals Handbook. 9th ed., Vol. 4, ASM, Ohio.

56. Ochoa E.A., Figueroa C.A., Alvarez F. (2005), The influence of the ion current density on plasma nitriding process, Surface and Coatings Technology, Vol. 200, 2165-2169. 
57. Olzon-Dionysio M., Campos M., Kapp M., de Souza S., de Souza S.D. (2010), Influences of plasma nitriding edge effect on properties of 316L stainless steel, Surface and Coatings Technology, Vol. 204, 3623-3628.

58. Olzon-Dionysio M., de Souza S.D., Basso R.O., de Souza S. (2008), Application of Mössbauer spectroscopy to the study of corrosion resistance in $\mathrm{NaCl}$ solution of plasma nitrided AISI 316L stainless steel, Surface and Coatings Technology, Vol. 202, 36073614.

59. Pinedo C.E., Monteiro W.A. (2004), On the kinetics of plasma nitriding a martensitic stainless steel type AISI 420, Surface and Coatings Technology, Vol. 179, 119-123.

60. Podgornik B., Vizintin J., Leskovsek V. (1998), Tribological properties of plasma and pulse plasma nitrided AISI 4140 steel, Surface and Coatings Technology, Vol. 108-109, 454-460.

61. Psyllaki P.P., Griniari A., Pantelis D.I. (2008), Parametric study on laser nitriding of 1.5919 steel, Journal of Materials Processing Technology, Vol. 195, 299-304.

62. Pye D. (2003), Practical Nitriding and Ferritic Nitrocarburizing, ASM International, Materials Park.

63. Raman S.S., Jayaprakash M. (2007), Influence of plasma nitriding on plain fatigue and fretting fatigue behaviour of AISI 304 austenitic stainless steel, Surface and Coatings Technology, Vol. 201, 59065911.

64. Ribeiro K.B., de Sousa R.M., de Araújo F.O., de Brito R.A., Barbosa J.P., Alves Jr. C. (2008), Industrial application of AISI 4340 steels treated in cathodic cage plasma nitriding technique, Materials Science and Engineering A, Vol. 479, 142-147.

65. Saeed A., Khan A.W., Jan F., Abrar M., Khalid M. Zakaullah M. (2013), Validity of "sputtering and re-condensation" model in active screen cage plasma nitriding process, Applied Surface Science, Vol. 273, 173-178.

66. Saklakoglu I.E., Saklakoglu N., Short K.T., Collins G.A. (2007), Characterization of austenitic stainless steel after plasma immersion nitrogen and carbon implantation, Materials and Design, Vol. 28, 1657-1663.

67. Sharma M.K., Saikia B.K., Phukan A., Ganguli B. (2006), Plasma nitriding of austenitic stainless steel in $\mathrm{N}_{2}$ and $\mathrm{N}_{2}-\mathrm{H}_{2}$ dc pulsed discharge, Surface and Coatings Technology, Vol. 201, 2407-2413.

68. Singh G.P., Alphonsa J., Barhai P.K., Rayjada P.A., Raole P.M., Mukherjee S. (2006), Effect of surface roughness on the properties of the layer formed on AISI 304 stainless steel after plasma nitriding, Surface and Coatings Technology, Vol. 200, 5807-5811.

69. Sirin S. Y., Sirin K., Kaluc E. (2008), Effect of the ion nitriding surface hardening process on fatigue behavior of AISI 4340 steel, Materials Characterization, Vol. 59, 351-358.

70. Sirin S.Y., Kaluc E. (2012), Structural surface characterization of ion nitrided AISI 4340 steel, Materials and Design, Vol. 36, 741-747.

71. Skolek-Stefaniszyn E., Kaminski J., Sobczak J., Wierzchon T. (2010), Modifying the properties of AISI 316L steel by glow discharge assisted low-temperature nitriding and oxynitriding, Vacuum, 85, 164169.

72. Sobiecki J. R., Mańkowski P., Patejuk A. (2004), Improving the performance properties of valve martensitic steel by glow dischargeassisted nitriding, Vacuum, Vol. 76, 57-61.

73. Soleimani S.Y., Mashreghi A.R., Ghasemi S.S., Moshrefifar M. (2012), The effect of plasma nitriding on the fatigue behavior of DIN 1.2210 cold work tool steel, Materials and Design, Vol. 35, 87-92.

74. Soltani Asadi Z., Mahboubi A. (2012), Effect of component's geometry on the plasma nitriding behavior of AISI 4340 steel, Materials and Design, Vol. 34, 516-521.

75. Sun Y., Bell T. (1998), Sliding wear characteristics of low temperature plasma nitrided 316 austenitic stainless steel, Wear, Vol. $218,34-42$.
76. Szabo A., Wilhelmi H. (1984), The mechanisms of nitriding of steel surfaces in a D. C. glow discharge, Haerterei Technische Mitteilungen, Vol. 39, 148-151.

77. Szilágyiné Biró A. (2013), Trends of Nitriding Processes, Production Processes and Systems, Vol. 6, 57-66.

78. Tibbetts G. G. (1974), Role of nitrogen atoms in "ion-nitriding", Journal of Applied Physics, Vol. 45, 5072-5073.

79. Toshkov V., Russev R., Madjarov T., Russeva E. (2007), On low temperature ion nitriding of austenitic stainless steel AISI 316, Journal of Acheivements in Materials and Manufacturing Engineering, Vol. 25, 71-74.

80. Tuckart W., Forlerer E., lurman L. (2007), Delayed cracking in plasma nitriding of AISI 420 stainless steel, Surface and Coatings Technology, Vol. 202, 199-202.

81. Wang J., Xiong J., Peng Q., Fan H., Wang Y., Li G., Shen B. (2009), Effects of DC plasma nitriding parameters on microstructure and properties of $304 \mathrm{~L}$ stainless steel, Materials Characterization, Vol. 60, 197-203.

82. Wang L., Ji S., Sun J. (2006), Effect of nitriding time on the nitrided layer of AISI 304 austenitic stainless steel, Surface and Coatings Technology, Vol. 200, 5067-5070.

83. Wang L., Ji S., Sun J. (2006), Effect of nitriding time on the nitrided layer of AISI 304 austenitic stainless steel, Surface and Coatings Technology, Vol. 200, 5067-5070.

84. Wang S., Cai W., Li J., Wei W., Hu J. (2013), A novel rapid D.C. plasma nitriding at low gas pressure for 304 austenitic stainless steel, Materials Letters, Vol. 105, 47-49.

85. Weber T., de Wit L., Saris F.W., Koniger A., Rauschenbach B., Wolf G.K., Krauss S. (1995), Hardness and corrosion resistance of single-phase nitride and carbide on iron, Materials Science and Engineering A, Vol. 199, 205-210.

86. Wen D.C. (2009), Plasma nitriding of plastic mold steel to increase wear- and corrosion properties, Surface and Coatings Technology, Vol. 204, 511-519.

87. Wierzchoń T., Psoda M., Skołek E., Rudnicki J., Sobiecki J.R. (2006), Glow discharge assisted nitriding of chromium steel $3 \mathrm{H} 13$, Maintenance Problems, Vol. 2, 53-64.

88. Winck L.B., Ferreira J.A., Araujo J.A., Manfrinato M.D., da Silva C.M. (2013), Surface nitriding influence on the fatigue life behavior of ASTM A743 steel type CA6NM, Surface and Coatings Technology, Vol. 232, 844-850.

89. Wu K., Liu G.Q., Wang L., Xu B.F. (2010), Research on new rapid and deep plasma nitriding techniques of AISI 420 martensitic stainless steel, Vacuum, 870-875.

90. Xi Y.T., Liu D.X., Han D. (2008a), Improvement of corrosion and wear resistances of AISI 420 martensitic stainless steel using plasma nitriding at low temperature, Surface and Coatings Technology, Vol. 202, 2577-2583.

91. Xi Y.T., Liu D.X., Han D. (2008b), Improvement of erosion and erosion-corrosion resistance of AISI 420 stainless steel by low temperature plasma nitriding, Applied Surface Science, Vol. 254, 5953-5958.

92. Xu B., Zhang Y. (1986), Collision dissociation model in ion-nitriding, $5^{\text {th }}$ International Congress on Heat Treatment of Materials, 10861093.

93. Zlatanović M., Popović I. (2010), Gas discharge static characteristics in pulse regime, Contemporary Materials, Vol. 1, 138143.

Acknowledgement: This scientific work was supported by the Faculty of Mechanical Engineering, Bialystok University of Technology, project No S/WM/1/2014. 